\title{
Uptake of Uranium by Callus Cultures of Two Acacia Species
}

\author{
Hana S. Al-Salih \\ Department of Biology \\ College of Sciences \\ University of Mosul
}

E-mail:

h.alsalih59@yahoo.co.uk
Riyad A. Fathi

College of Environment

University of Mosul

E-mail:

riyadaltaai@yahoo.com
Godbold D. Davey J. Environment Center Wales

Bangor University

$U K$

(Received 16/5/2012; Accepted 25/6/2012)

\begin{abstract}
This study aimed to use callus cultures of Acacia trees as indicator for the validity of employing these trees in the phytoremediation programs that were used to manage the pollution with uranium in soil. Various concentrations of uranium $(0.0,50,100,200,500$ and $\left.1000 \mathrm{mg} \cdot .^{-1}\right)$ in the form of uranyl nitrate were added to MS medium that used for the initiation and growth of Acacia callus in the presence of $0.5 \mathrm{mg} / 1$ of each NAA and BA. For comparison, two species of Acacia were used in this study, A. albida and A. nilotica. Fresh and dry weight of callus was determined along three growth periods (30, 60 and 90 days). levels of uranium in callus cells were determined using TXRF analysis. The Results showed that fresh and dry weight of callus increased with the increase of uranium concentrations except that grown on MS with $1000 \mathrm{mg} . \mathrm{l}^{-1}$ of uranium in which inhibition in both fresh and dry weight of callus after three months of growth was recorded .Analysis of the cellular content of uranium using TXRF revealed that the maximum level obtained when callus grown on MS with $500 \mathrm{mg} \cdot 1^{-1}$.
\end{abstract}

\section{إستالب اليورانيوم من قلى مزارع الكالس النوعين من الكلسيا}

\section{الملغص}

هذفت الدرلسة اله لستخدلم كاللس لشجار اللكلسيا بوصفها مؤثررت لقيم لستخدلم لشجار الكلسيا في

برلمج المعالجة النباتية المستخمة في معالجة تلوث التربة باليورانيوم. ترلكيز مختلفة من اليورانيوم (بشكل

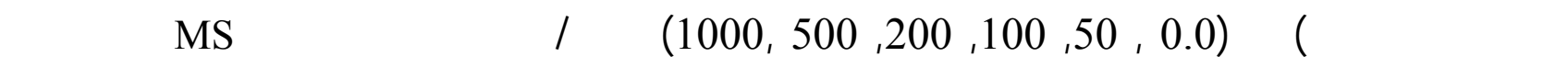
0.5 ملغم /لتر من كل من BA و NAA وهو الونط المستخدم في هذه الدرلسة للاستحداث ونموالكالس لاشجار الكلسيا .ولابل المقارنة لمتخدم في هذه الدرلسة نوعان من ألشجار الكلسيا هما

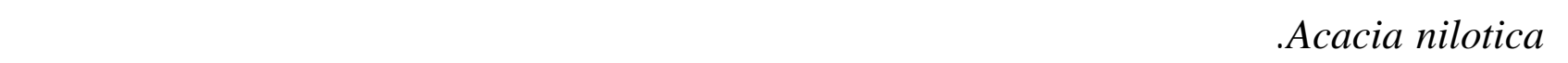
30 و60 و90 يوما، كما مق قيلس مستوى اليورانيوم في خلايا الكاللس بلجراء تحليل TXRF. بينت النتائج ان الوزن الطري والوزن الجف للكالس ازداد مع زياة ترلكيز اليورانيوم المضافة اله الوسط الغذائي ماعدا 


\section{الونط المضف اليه 1000 ملغم /لتر الذي لشارت النتائج اله حصول انخفاض بالوزن الطري ترافق ذك

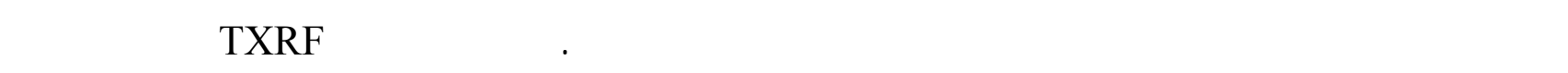

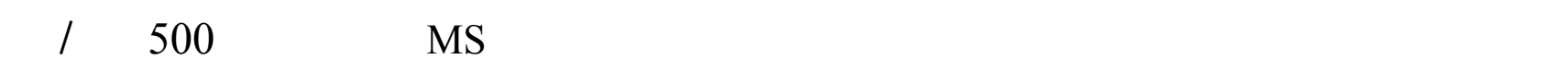 من اليورانيوم.}

\section{INTRODUCTION}

Metal contamination found within food grown in Iraq exceeds current WHO (World Health Organization ) levels in some of the regions and there is a serious concern about the presence of depleted uranium in Iraq. The Iraqi environment, in some regions, is heavily polluted by various toxic metals and radioactive pollution especially in the soil, water and air. So, any mechanism for reducing the environmental exposure to depleted uranium will greatly reduce the risk of human. Plants were suggested to be used in removal and stabilization of metal contaminants (Belimov, et al., 2003; Meagher, 2000). Progress has been made in recent years by using plants and other organisms for the remediation of environmental contaminants. These technologies depend on different living organisms like plants, green algae, fungi, bacteria etc.(McGrath et al., 1993). It was showed that plants might be used to remove metals from polluted soils (Cunningham et al.,1997; SasNowosielskaa, 2004).

Phytoremediation is the major part of bioremediation, a promising technology using plants to remove contaminants as heavy metals and radioactive elements from the environment rendering them harmless; it is actually a generic term for several ways in which plants can be used to clean up contaminated soils and water. The mechanisms of phytoremediation include enhanced rhizosphere biodegradation, phyto-extraction (also called phyto-accumulation), phyto-degradation, and phyto-stabilization and finally defined as the use of living green plants for cleaning up sites from organic and inorganic pollutant (Sas-Nowosielskaa, 2004). Uranium translocation among tissues of Indian mustard Brassica juncea plants is in the relation of roots $>$ shoots $>$ leaves, and Indian mustard is recommended as a potential species for phytoextraction for U-contaminated soil due to its high $U$ accumulation of above ground biomass ( $2200 \mu \mathrm{g}$ per plant) (Chang et al., 2005).

Accumulation of Uranium in plant tissues was studied in the shoots and roots of corn - maize (Zea mays), grown on two types of soils, pseudogley and chernozem, together with its phytotoxic effect on plant growth and development. The soils were contaminated with different rates (10 to $1000 \mathrm{mg} \mathrm{U}(\mathrm{VI}) \mathrm{kg}-1)$ of uranyl nitrate $\left(\mathrm{UO}_{2}\left(\mathrm{NO}_{3}\right)_{2} \cdot 6 \mathrm{H}_{2} \mathrm{O}\right)$, they found a linear dependence between the content of uranium in soil and in plant tissues (Stojanović et al., 2010). Sunflower was shown to be very effective in recovering U from Ucontaminated water. Uranium accumulated mainly in the roots, with concentrations 5,000 to 10,000 times greater than that in the water (Olowoyoa et al., 2012 ; Huang et al., 1998), Phytoremediation of uranium (U) contaminated soil has been hampered by a lack of information relating $U$ speciation to plant uptake.

This study was carried out to understand the uptake of uranium by callus cells derived from two species of Acacia, A.albida and A. nilotica that's to make decision for choosing Acacia trees to be used in phytoremediation programs in the contaminated sites in Iraq. It is important to mention that this study is part of a project that uses the field experiments and 
callus cultures of these trees. Acacia trees which belong to the family Fabaceae (Leguminosae), are one of the largest families of flowering plants, subfamily Mimosoideae mostly trees or shrubs numbering 630 genera and 18,000 species, there are approximately 2379 species in the Acacia genus, distributed from Africa around the Indian Ocean to tropical Asia and Australia and in the tropical Americas.

Acacia albida, Botanical Name: Faidherbia albida, is drought resistant and native in Africa and the Middle East and Arabia, the tree is widespread in semiarid areas of Africa. Over 20C. was usually found on a wide range of soil types and within varying climates and habitats it prefers semiarid, alluvial, revering zones and depressions with water present below the surface (Van Wyk, and Van Wyk 1997).

Acacia nilotica, very naturally widespread species in the drier areas of Africa from Senegal to Egypt and down to South Africa and in Asia from Arabia eastwards to India, Burma and Sri Lanka. It has also been cultivated elsewhere, including Australia, Cape Verde islands, Indonesia, Iran, Iraq, Nepal, Vietnam, and the West Indies. It is divided into nine subspecies. Usually $2.5-15 \mathrm{~m}$ tall, but reaching $25 \mathrm{~m}$ or more in the riverine subspecies, with root system deep and extensive in dry sites, the taproot developing first and then the laterals, which become compact and massive(Fagg and Greaves,1990).

\section{MATERIALS AND METHODS}

Seeds of A.albida and A. nilotica were imported from -5 Pakistan (stored at $3-5^{0} \mathrm{C}$ ), by the Environment Center of Wales /Bangor University/UK, in which all the experiments of this study were carried out. The seeds were surface sterilized using ethanol $95 \%$ for two minutes. then $2 \%$ sodium hypochlorite (Sigma) for 12 minutes. followed by five separate rinses with sterile distilled water 2 minutes each. After then, the explants were transferred on sterilized filter paper. Sterilized seeds were cultured on Arnon and Hoagland medium (Arnon and Hoagland, 1944) for germination. Sterilized seedlings used as a source for explants were shown in (Fig.1).

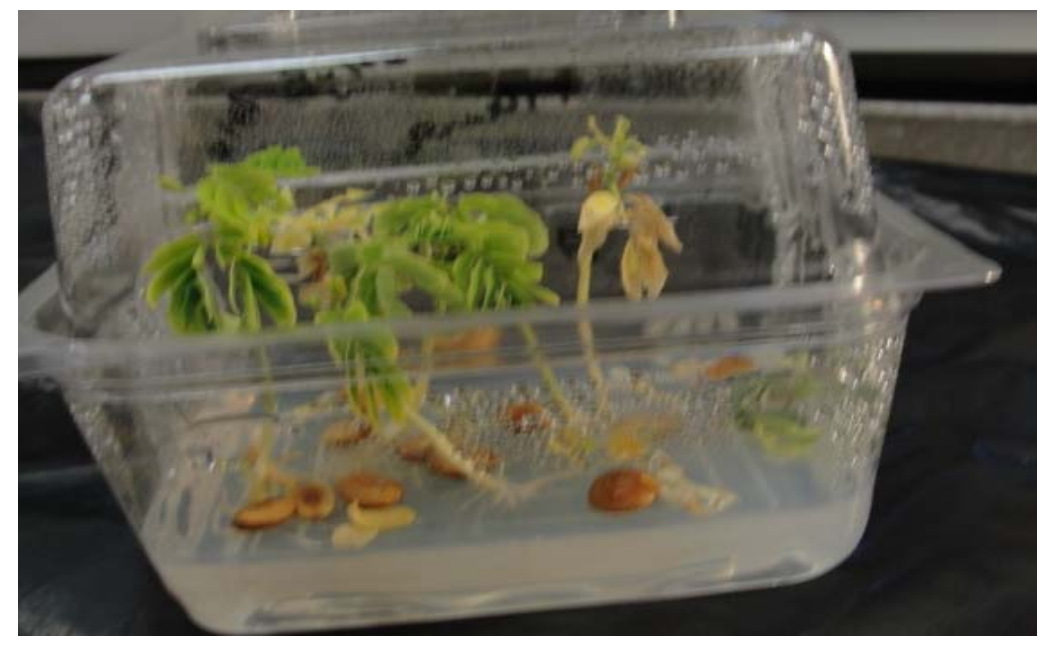

Fig. 1 : Sterilized seedlings of A.albida that used as a source for the explants. 


\section{Source of explants:}

Explants used for the initiation of callus were taken from a stem (explants used were both with node and without node, they are used for the initiation of callus), root, leaf, and cotyledons of 25-30 days seedlings. The cultures were kept on using growth cabinet supplemented with a $16 \mathrm{~h}$ light and $8 \mathrm{~h}$ dark, $25-30^{\circ} \mathrm{C}$ day-night regime with $70 \%$ humidity. jars as shown in figure-1- or $9 \mathrm{~cm}$ I.D. Petri dishes were used in this study depending on the experiment. All these explants in addition to the callus were used for treatment with uranium concentrations as well.

\section{Callus initiation \& growth:}

To initiate callus sterilized seedlings of 25-30 days old were excised into $1-1.5 \mathrm{~cm}$ explants for the stem and root, $0.5 \mathrm{~cm}^{2}$ for the leaves and cotyledons, these explants were cultured on MS (Murashige and Skoog, 1962) medium, solidified with $7 \mathrm{~g} / 1$ of agar and addition of $35 \mathrm{~g} / 1$ sucrose. Plant growth regulators used were $0.5 \mathrm{mg} / \mathrm{l}$ of each NAA and BA respectively. Callus was recultured on fresh medium ( as mentioned above ) every 30 days for maintenance of growth.

\section{Determination of callus fresh and dry weight:}

Callus derived from stem explants were cultured on MS medium as mentioned above but with the addition of various concentrations of uranium(as Uranyl Nitrate $\left.\mathrm{UO}_{2}\left(\mathrm{NO}_{3}\right)_{2}\right)$ $(50,100,200,500$ and 1000) $\mathrm{mg} / \mathrm{l}$, then let to grow for 90 days for albida ,but for 60 days in case of nilotica for the reasons that this species was more sensitive for temperature and needs more time for callus initiation. In each 30 days period, fresh and dry weight was determined.

\section{TXRF study:}

Callus grown on MS media with the different conc. (50, 100, 200, 500, and 1000mg/l) of Uranium were analyzed by TXRF (Total Reflection X-ray Fluorescence Spectrometer) (Bruker,S2 PICOFOX, USA).

For that callus dried at $80{ }^{\circ} \mathrm{C}$ for 24 hours, grinded by ball mill and sieved to $<25 \mu \mathrm{m}$ to remove any large particle. Between $20-30 \mathrm{mg}$ of each sample was diluted with $1 \%$ Triton in aliquot. $10 \mu \mathrm{l}$ of arsenic was added as standard. $5 \mu \mathrm{l}$ of the homogenised sample was applied directly into a polished carrier made of quartz or acrylic glass, and dried on a hot plate $\left(80{ }^{0} \mathrm{C}\right)$. The discs were then placed in the TXRF for the analysis of uranium and other elements in plants by a quantitative analysis.

\section{RESULTS \\ Response of seedling parts to initiate Callus:}

The highest response for callus initiation was observed in seedling stem segments that showed $83 \%$ response as compared to $26 \%$ for the root explants and $13 \%$ for the cotyledons explants, whereas leaf explants respond with a very low rate $2 \%$ (Fig. 2), these results were expected, if we know that stem contains the high ratio of parenchymatous cells as compared with root, cotyledons and leaves, which considered to be the target cells that got the signal and initiate callus. The results showed that callus formed from stem, root and cotyledons was friable yellowish (Fig. 3 and 4). 


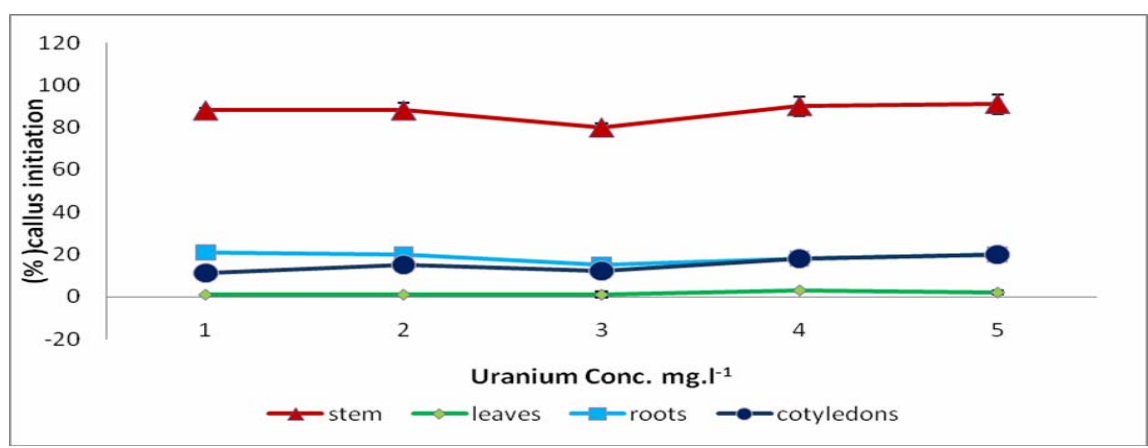

Fig. 2: Response (\%) of different seedling explants sources to initiate callus using MS medium with the addition of $0.5 \mathrm{mgl}^{-1}$ of $\mathrm{BA}$ and NAA and different conc. of Uranium as Uranyl nitrate.
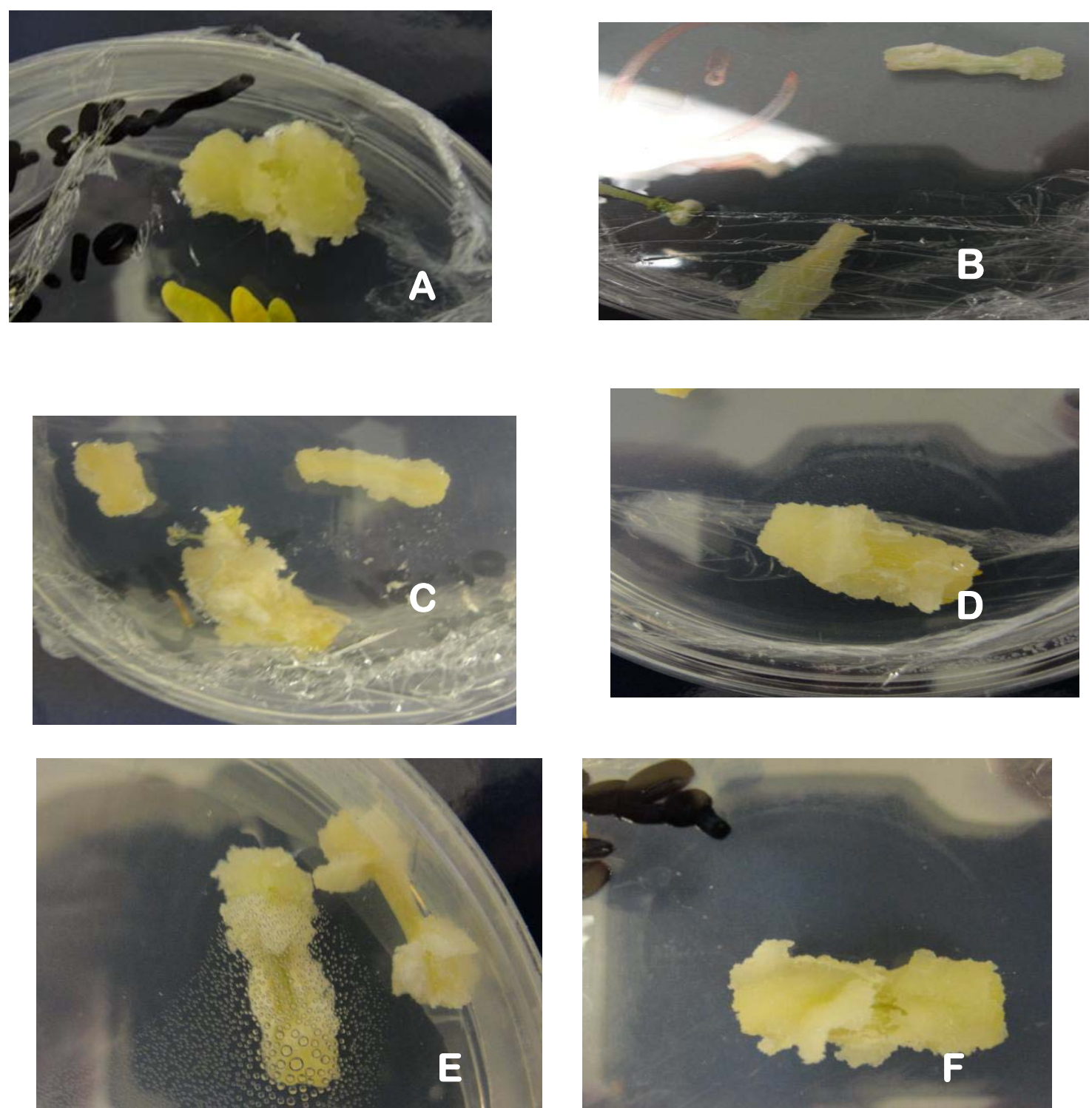

Fig. 3 : Response of seedling stem explants to initiate callus after 30 days of culture on MS medium supplemented with $0.5 \mathrm{mg}^{-1} \mathrm{l}^{-1}$ each BA and NAA and different concentrations of Uranium: A-Control, B- 50, C- 100, D-200, E-500, F-1000 mg. $\mathbf{l}^{-1}$. 

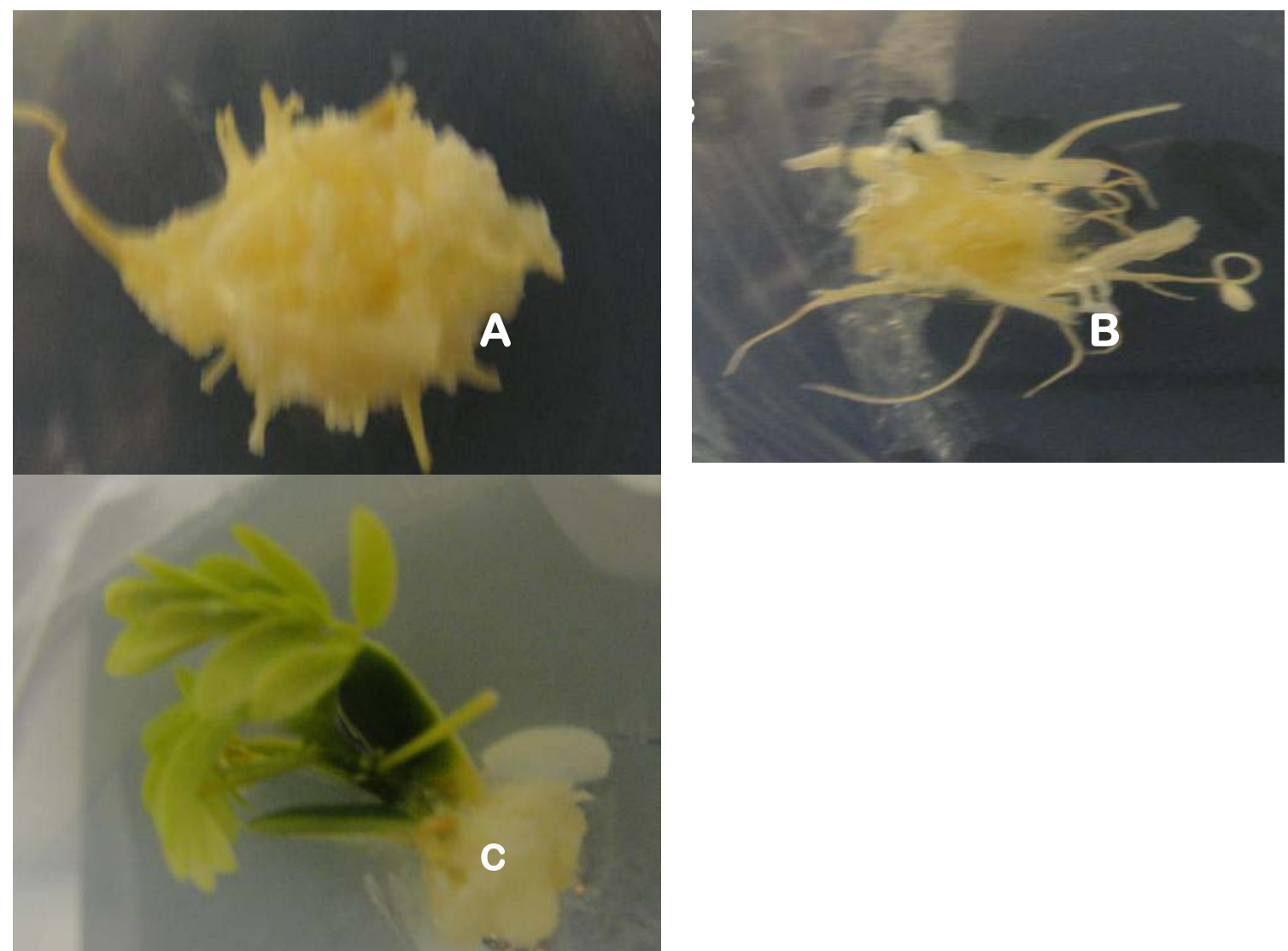

Fig. 4: Response of root and Cotyledon explants to initiate callus after 30 days of culture on MS medium supplemented with $0.5 \mathrm{mg}^{-1} \mathrm{l}^{-1}$ each BA and NAA and different concentrations of Uranium: A-root

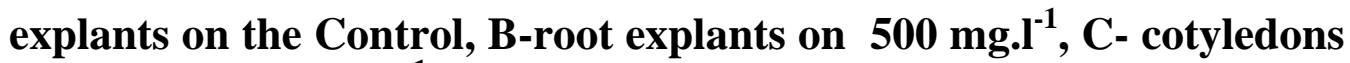
explants on $500 \mathrm{mg}^{\mathrm{I}^{-1}}$.

\section{Callus Fresh Weight}

\section{A. Acacia albida}

Fig. 5 shows that callus fresh weight fluctuated with the concentration of uranium in the medium. At the first stage of growth (30 days), the results showed that callus fresh weight in the treatment of 100 and $200 \mathrm{mg} \cdot \mathrm{l}^{-1}$ uranium was 1.47 and $1.42 \mathrm{~g}$, which is very close to that $(1.46 \mathrm{~g})$ for the control, whereas with all other treatments of uranium $(50,500$, $\left.1000 \mathrm{mg} . \mathrm{l}^{-1}\right)$ callus fresh weight was less. The lowest fresh weight $(0.88 \mathrm{~g})$ was for the callus treated with $1000 \mathrm{mg} . \mathrm{l}^{-1}$, this probably because a high concentration may have a negative effect on cell growth, Stojanović et al., (2010) studied the accumulation of Uranium in plant tissue shoots and roots of corn - maize (Zea mays), grown on two types of soils, pseudogley and chernozem, together with its phytotoxic effect on plant growth and development, they reported that the soils were contaminated with different rates (10 to 1000 $\mathrm{mg} \mathrm{U}(\mathrm{VI}) \mathrm{kg}^{-1}$ ) of uranyl nitrate.

In the second and third stage of growth (60 and 90 days), callus fresh weight gave the highest values $(2.02$ and $2.32 \mathrm{~g})$ in the treatment of $500 \mathrm{mg} . \mathrm{l}^{-1}$ while in other treatments, callus fresh weight was less, this is probably due to the role of nitrate within the uranium that enhances callus growth, that's because we used uranium in the form of uranyl nitrate. 
The statistical analysis showed that it is highly significant $\mathrm{P} \leq 0.01$. The callus seems to be friable with yellowish white color.

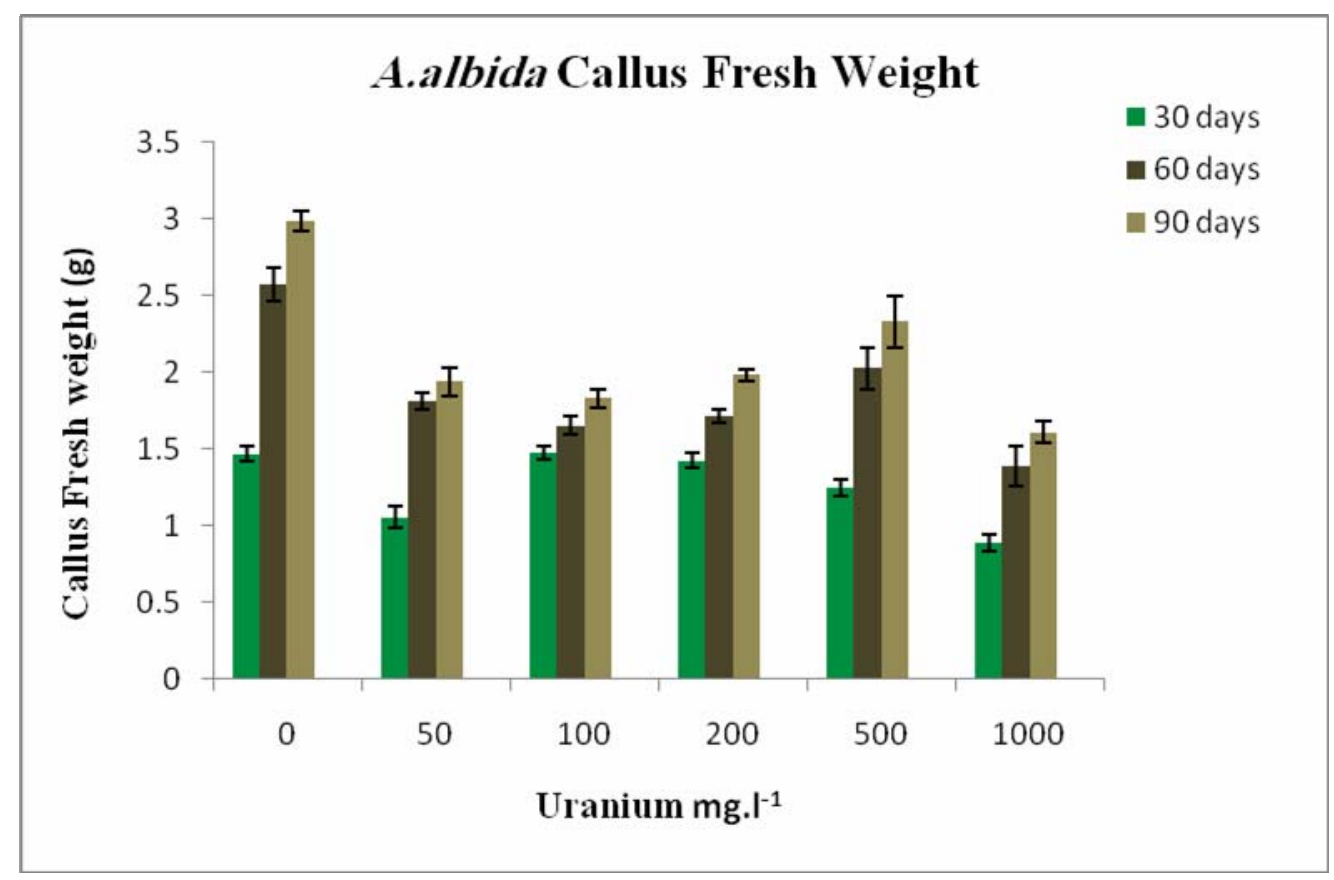

Fig. 5: A.albida Callus fresh weight after 30,60 and 90 days of growth on MS medium with $0.5 \mathrm{mg.l}^{-1}$ of BA and NAA , and addition of different conc. of Uranium.

\section{B - Acacia nilotica}

Callus fresh weight of A.nilotica showed to be highly significant $\mathrm{P} \leq 0.01$ for the concentration and age but for the relation between conc. and age the statistical analysis showed to be non-significant. The fresh weight of callus (Fig. 6) varied with the variation of uranium concentrations in the medium, it seems that the stimulation for callus initiation and growth is less than that in A.albida. callus fresh weight in the control treatment reached to $0.93,1.37 \mathrm{~g}$ after 30 and 60 days of growth compared with 1.46 and $2.57 \mathrm{~g}$ for the control treatment of A.albida (Fig. 5), this is probably due to that explants from A. nilotica did not respond in the same manner as other species in tissue culture systems, or it is due to the less active seedlings of $A$. nilotica compared with A.albida but when treatmented with uranium, the results showed that callus growth increased with the increase of uranium concentrations (50-1000 mg. $\mathrm{l}^{-1}$ ). This result leads to the fact that $A$. nilotica can accumulate higher conc. of uranium, as compared with A. albida in which the callus fresh weight decreased when treated with $1000 \mathrm{mg} \cdot \mathrm{l}^{-1}$ as mentioned above. The callus seems to be more compact in texture than that of albida (Fig. 7). In general, it is clear that the growth of A. nilotica callus is not active as with $A$. albida, for that we depended on A. albida in all the following experiments related to the uptake of uranium and its effect on fresh and dry weight. 


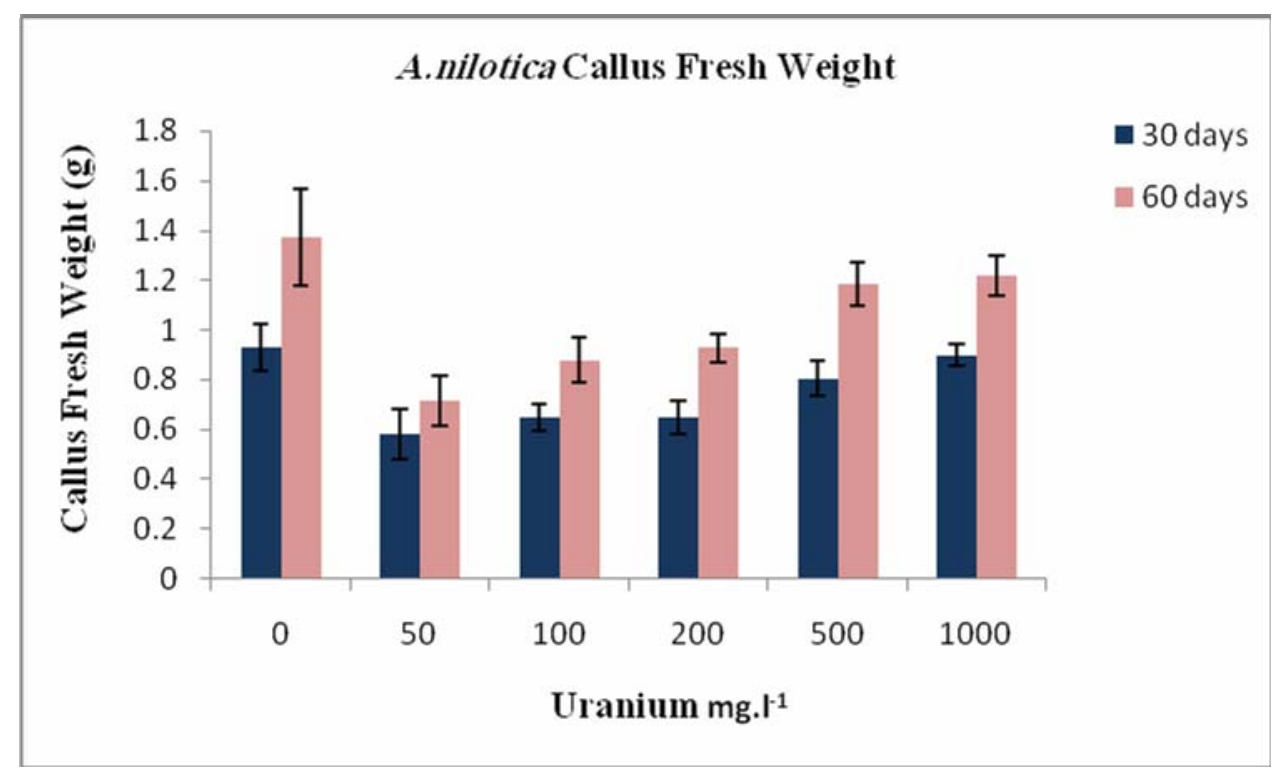

Fig. 6: A. nilotica Callus fresh weight after 30,60 days of growth on MS medium with

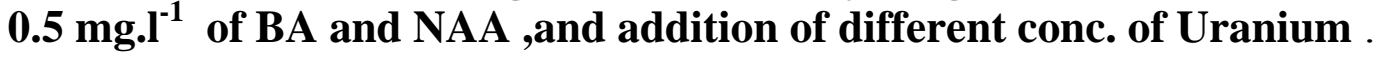

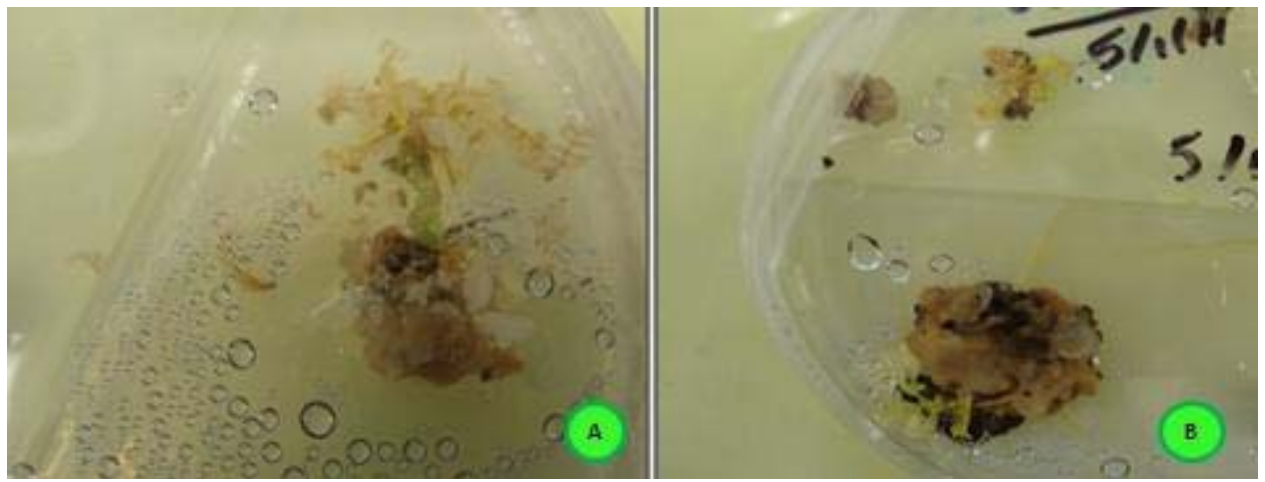

Fig. 7 : A. nilotica callus grown for 50 days on MS medium with A-500, B- 1000 mg.l-1 of uranyl nitrate.

\section{Dry Weight}

\section{A- A.albida}

The highest value of callus dry weight is shown to be 0.263 and $0.267 \mathrm{~g}$ for the treatment with 200 and $500 \mathrm{mg}^{-1}{ }^{-1}$ respectively, while the most reduction in dry weight was recorded with the treatment of 50 and $1000 \mathrm{mg} \cdot 1^{-1}$, this is in the case of the first 30 days of growth (Fig. 8). but for the 60 and 90 days of growth the results showed that the most reduction in dry weight happened with the treatment of 100 and $200 \mathrm{mg} . \mathrm{l}^{-1}$ of uranium in which the dry weight reached to $(0.312$ and $0.311 \mathrm{~g})$ after 60 days and $0.356,0.34 \mathrm{~g}$ for 90 days. It is clear from the results in (Fig. 8) that after 90 days of growth dry weight for the treatments of 500 and $1000 \mathrm{mg} .1^{-1}$ reached the highest values of 0.421 and 0.390 which are near to that of the control treatment $(0.465 \mathrm{~g})$. The statistical analysis showed that it is highly significant $\mathrm{P} \leq 0.01$ for the age and uranium concentrations, but it is non-significant for the relation between age and concentrations. 


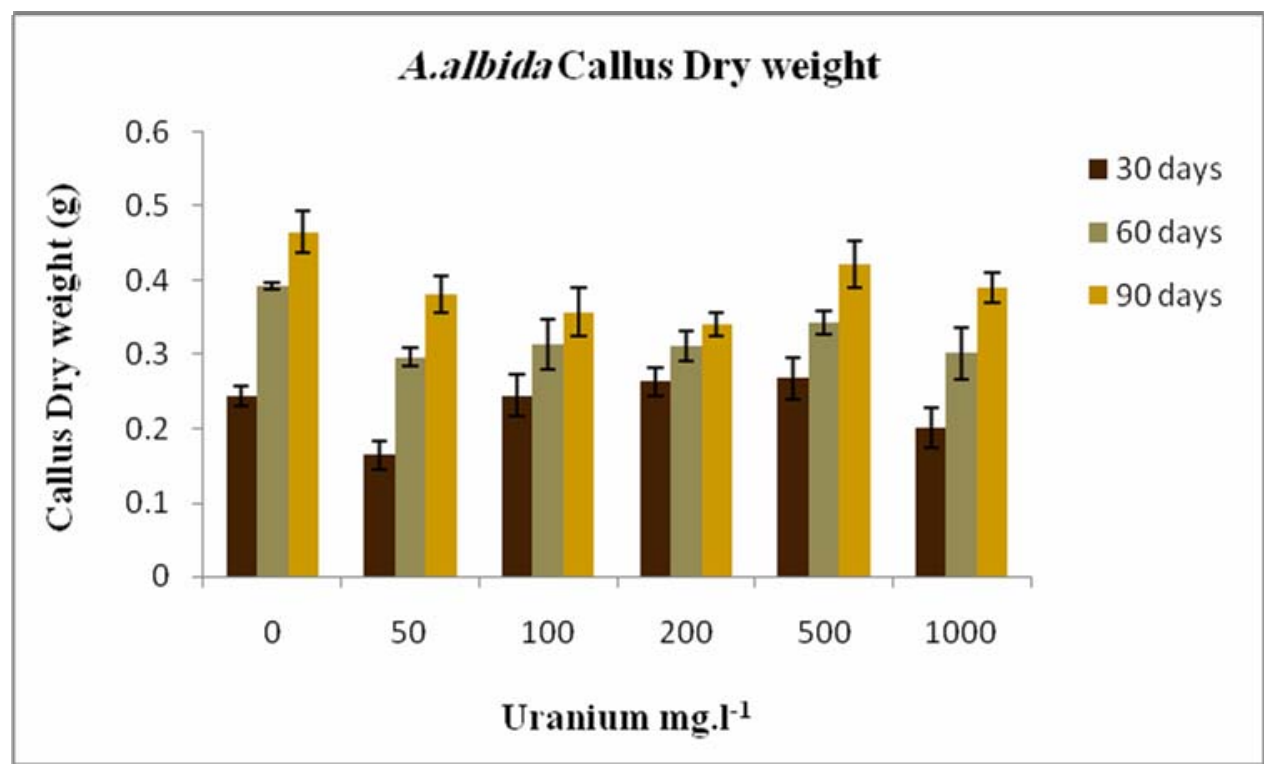

Fig. 8: Callus dry weight of A.albida after 30,60 and 90 days of growth on MS medium with addition of of $0.5 \mathrm{mg}^{-1} \mathrm{l}^{-1}$ each $\mathrm{BA}$ and NAA and concentrations of Uranium.

\section{B- $\quad$ A.nilotica}

Callus dry weight of A.nilotica showed to be highly significant $\mathrm{P} \leq 0.01$ for the conc. and the age but it is non significant for the relation between them. The results showed that the dry weight reduced as compared with that of $A$ albida. In the two stages of growth 30 and 60 days the dry weight showed a positive correlation with the uranium conc. used (Fig. 9). Also it is similar to the mode of increase in fresh weight (shown in Fig. 6). All the values of dry weight in all the treatments showed to be less than the control treatment, except that for the $1000 \mathrm{mg} . \mathrm{l}^{-1}$ that reached to levels of 0.124 and $0.153 \mathrm{~g}$ after 30 and 60 days which are close to those in the control treatment $(0.148$ and $0.21 \mathrm{~g})$ in the same stages.

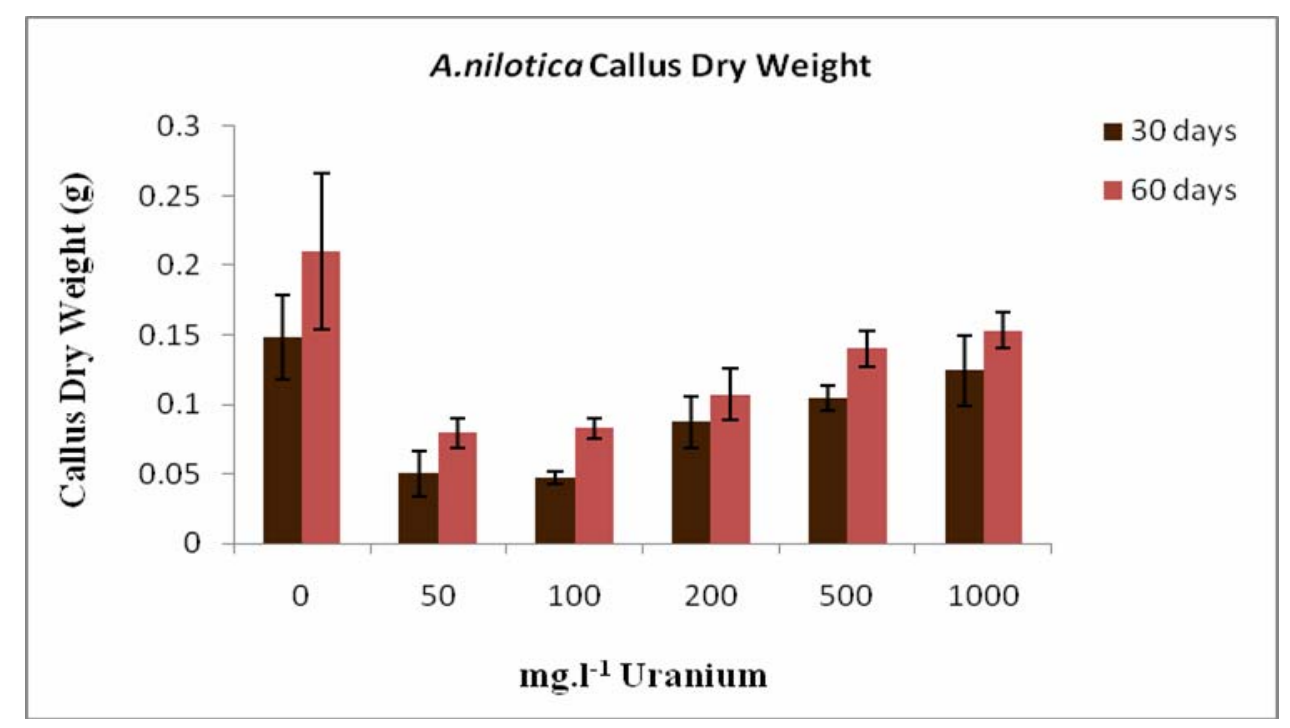

Fig. 9. : Callus dry weight of A.nilotica after 30 and 60 days of growth on MS medium with addition of $0.5 \mathrm{mg}^{-1}$ of each BA and NAA and concentrations of Uranium. 


\section{TXRF analysis:}

Results of TXRF analysis (Fig. 10) showed that in case of using uranium in the form of Uranyl nitrate, the uptake of uranium increased with the increase of conc. $50-500 \mathrm{mg} .1^{-1}$, after that there is a decrease with the treatment of $1000 \mathrm{mg} . \mathrm{l}^{-1}$, but it is still with higher value than those for the treatments of 50,100 and $200 \mathrm{mg} . \mathrm{l}^{-1}$. The Statistical analysis showed that it is HS $\mathrm{P} \leq 0.01$ in comparison with the above results of fresh weight. Results showed that the fresh weight also decreased in the treatment of $1000 \mathrm{mg} . \mathrm{l}^{-1}$, this is probably due to that A.albida callus could accumulate uranium and make use of the nitrate (Uranyl nitrate) to enhance growth, but with $1000 \mathrm{mg} .1^{-1}$ it is clear that the growth of callus affected by both uranium and nitrate high conc, especially if we keep in mind the conc, of nitrate already exist in MS medium.

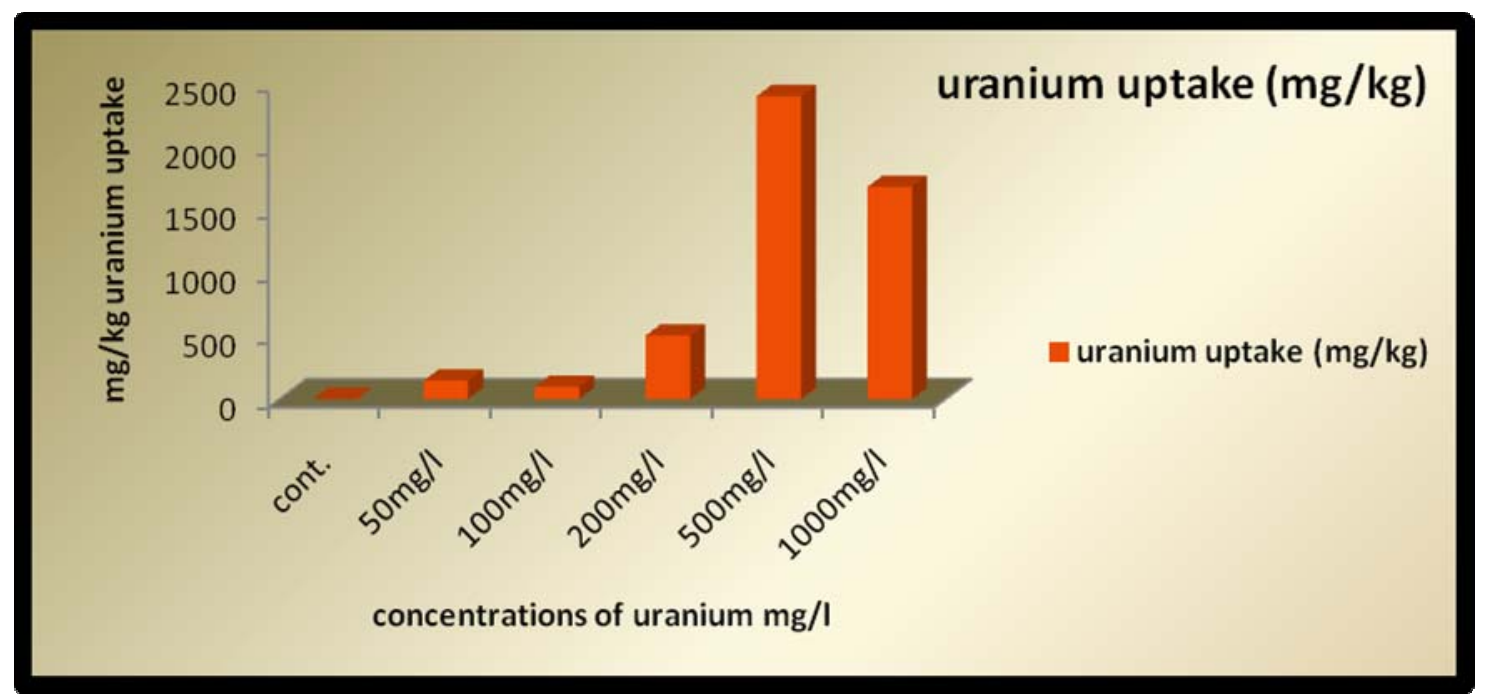

\section{Fig. 10: TXRF analysis of uranium uptake by A. albida callus after 60 days of growth on MS medium supplemented with 0.5 mg. $^{-1}$ of each NAA and BA and different concentrations of uranium.}

\section{DISCUSSION}

Plant tissues grown in vitro provide an ideal research tool for the study of a wide range of aspects of plant science. It is also being increasingly adopted for the commercial propagation of plants (George et al., 2008; Karuppusamy, 2009; Rai, 2007).

Tissue culture techniques offer not only an excellent opportunity to study the factors that elicit the totipotentiality of cells but also allow the investigation of factors controlling cytological and histological differentiation (Bhojwani and Razdan, 1996).

The results of this project revealed that stem explants were the best source to initiate callus, whereas leaves, root and cotyledons explants exhibit callus initiation but with a longer time and less growth average, these results may be due to that stem contains the high ratio of parenchymatous cells as compared with root, cotyledons and leaves, which were considered to be the target cells that got the signal and initiate callus (Razdan, 2003). For that reason, seedling stem explants were used in this study in all the experiments of callus initiation. Many studies referred to considered stem explants as the best source for callus initiation. In the system of tissue culture, callus induction depends on the parenchyma cells 
that possess totipotency ability; however, sterile seedlings and not woody stem tissue tend to facilitate ease of callus initiation (George et al., 2008).

One of the successful reports that refers to callus formation and plantlets are developed from five Acacia species, A.senegal, A. albida, A. nilotica, A. koa and A. ligulata. These reports also include callus raised through seedling shoot tip cultures of Acacia koa, cotyledonary buds of $A$. albida, stem cultures of $A$. senegal, shoot cultures from mature plants of $A$. ligulata and regeneration of nodes and internodes of field grown young twigs of A. nilotica (Mittal et al., 1989). Another study in 1995 (Rout et al., 1995) reported that callus also derived from immature cotyledons of Acacia catechu Willd. Cotyledonary segments expanded on all media 8-10 days after inoculation. Callus formed on the entire surface and developed into a mass of callus after 16-18 days of culture depending on the auxin and cytokinin concentration in the culture media. It was found that media supplemented by either NAA or 2,4-D along with kinetin or BA stimulated rapid proliferation of callus. The largest callus formation was obtained with WPM (woody plant medium) supplemented with kinetin, NAA and 3\% sucrose and callus formed faster in the dark than in the 16-h photoperiod. They noticed that the explants cultured on WPM containing 2,4-D produced friable yellowish-brown callus, whereas callus formed in presence of NAA was more compact and deep yellowish (Rout et al., 2008).

Results for the uptake of uranium by callus cells showed that uranium uptake increases with the increase of its concentration until reaching $500 \mathrm{mgl}^{-1}$. After that, uptake decreased (when addition of $1000 \mathrm{mgl}^{-1}$ to the medium). Also callus growth was not affected by uranium concentration during the first two months of growth, but from the third month and thereafter callus growth slightly decreased and browning appeared on callus cultures. Although reculture of callus after each 30 days helped to recover its activity, its growth never recovered to that of the control treatment, and this means that a level of uranium was being accumulated in the cells and affecting callus viability. These results were supported by the TXRF analysis which showed the same model for uranium uptake. This led to the conclusion that acacia callus could accumulate uranium. To date about 400 plants that hyperaccumulate metals have been reported. The dominating hyperaccumulating families are Asteraceae, Brassicaceae, Caryophyllaceae, Cyperaceae, Cunouniaceae, Fabaceae, Flacourtiaceae, Lamiaceae, Poaceae, Violaceae, and Euphobiaceae (Prasad and Freitas, 2003).

Growth in vitro is highly dependent on the interaction between naturally occurring endogenous growth substances and an analogous growth regulator added to the medium. The origin of the explants, the type of culture, and other medium constituents are also important factors affecting callus initiation and growth. Callus composed of cell aggregates of parenchyma cells obtains nutrients directly from the medium, and in this it differs from the organized tissues in the whole plants (Hartmann et al., 2002). The suggestion here that callus cells are sensitive indicators for toxic elements (like uranium in our study). The similar differential sensitive form between the two Acacia species grown both as callus and whole plants, suggest that callus could be used to assess plants for phytoremediation programs. 


\section{ACKNOWLEDGEMENT}

This is part of the project which was supported by grant from the Council of Academic Refugee Assistant (CARA) under Iraq research fellowship program with the contribution of University of Bangor-UK. Under supervision of Professor Douglas Godbold and Davy Jones. The authors would like to thank all staff of CARA and ECW-SENRG -University of Wales - Bangor for their support in conducting this project.

\section{REFERENCES}

Arnon, D. I. ; Hoagland, D. R. (1944). The investigation of plant nutrients by artificial culture methods'. Boil. Rev., 19, 55-67.

Belimov, A. A. ; Safronova, V. I. ; Tsyganov, V. E.; Borisov, A.Y. ; Kozhemyakov, A. P. ; Stepanok, V. V.; Martenson, A. M.; Gianinazzi-Pearson, V. ; Tikhonovich, I. A. (2003). Genetic variability in tolerance to cadmium and accumulation of heavy metals in pea (Pisum sativum L.), Euphytica. 131, 25-35,

Bhojwani, S.S.; Razdan, M. K. (1996). "Plant Tissue Culture: Theory and Practice. Elsevier", Amsterdam-Lausanne-New York-Oxford-Shannon-Tokyo, pp. 337376.

Chang, P.; Kim, K.W.; Yoshida, S. ; Kim, S.Y. (2005). Uranium accumulation of crop plants enhanced by citric acid', Environmental Geochemistry and Health 27(5-6), 529-38.

Cunningham, S. D.; Shann, J.R.; Crowley, D. E. ; Anderson, T.A. (1997). "Phytoremediation of Contaminated Soil and Water, in Phytoremediation of Soil and Water Contaminants", E.L. Kruger, T.A. Anderson, and J.R. Coats, Eds., ACS Symposium Series 664, American Chemical Society, Washington, DC.

Fagg, C.W. ; Greaves, A. (1990). Acacia nilotica 1869-1988, CABI/OFI Annotated bibliography No. F42, CAB International, Wallingford, Oxon, UK.

George, E.F.; Hall, M.A. ; Klerk, J.D. (2008). "Plant Propagation by Tissue Culture". Vol. 1. The Background, Springer, pp. 65-75.

Hartmann, H.T.; Kester, D.E.; Davies, F.T. ; Geneve, R.L. (2002). "Plant Propagation Principles and Practices", Pearson Educational, Upper Saddle River, New Jersey.

Huang, J.W.; Blaylock, M.J.; Kapulnik, Y. ; Ensley, B.D. (1998). Phytoremediation of uranium-contaminated soils: role of organic acids in triggering uranium hyperaccumulation in plants. Environ. Sci. Technol. 32(13), 2004-2008.

Karuppusamy, S. (2009). A review on trends in production of secondary metabolites from higher plants by In Vitro tissue, organ and cell cultures. J. Medicinal Plants Research, 3 (13), 1222-1239 .

McGrath, J.A.; Ishida-Yamamoto, A.; O'Grady, A.; Leigh, I. M.; Eady, R. J. (1993). Structural variations in anchoring fibrils in dystrophic epidermolysis bullosa: correlation with type VII collagen expression. J. Invest. Dermatol . 100, 366-372,

Meagher, R.B. (2000). Phytoremediation of toxic elemental and organic pollutants. Curr Opin. Plant Biol 3: 153-162 Salt DE, Smith RD, Raskin I (1998). Phytoremediation. Annu Rev Plant Physiol Plant Mol Biol 49, 643-668.

Mittal, A.; Aggrawal, R.; Gupta, S.C. (1989). In vitro development of plantlets from axillary buds of Acacia auriculiformis- a leguminous tree. Plant Cell Tissue Organ Cult. 19, $65-70$ 
Murashige, T. ; Skoog, F. (1962). A revised medium for rapid growth and bioassays with tobacco tissue culture', Physiol Plant. 15, 473-497.

Olowoyoa, J. O.; Okedeyib, O. O.; Mkoloa, N. M.; Liona, G. N. ; Mdakanea, S. T. R. (2012). Uptake and translocation of heavy metals by medicinal plants growing around a waste dump site in Pretoria, South Africa, South African J. Botany. 78, 116-121.

Prasad , M.N.V. ; Freitas, H.M.de O. (2003). Metal hyperaccumulation in plants biodiversity prospecting for phytoremediation technology. Electronic $J$. Biotechnology. 6, 3.

Rai, R. (2007). "Genetics and Plant Breeding: Introduction To Plant Biotechnology". NewDelhi-110012, http://nsdl.niscair.res.in/bitstream/123456789/668/1/revised+introduction+to+plant +biotechnology.pdf.

Razdan, M.K. (2003) . "Introduction to Plant Tissue Culture". 2nd edn., Scientific Publishers, Inc., Enfield, NH.

Rout, G.R.; Senapati, S.K. ; Aparajeta, S. (2008). Micropropagation of Acacia chundra (Roxb.) DC. Horticultural Science 35( 1), 22-26.

Rout, G.R.; Samantary, S. ; Das, P. (1995). Somatic embryogenesis and plant regeneration from callus culture of Acacia catechu - a multipurpose leguminous tree. Plant Cell Tiss. Org. Cult. 42, 283-285.

Sas-Nowosielskaa, A. ; Kucharskia, R. ; Małkowskib, E. ; M. Pogrzebaa, M.; Kuperbergc, J. M.; Kryńskia, K. ( 2004). Phytoextraction crop disposal—an unsolved problem, Environmental Pollution, 128( 3) , 373-379.

Stojanović, M.D.; Stevanović, D.R.; Milojković, J. D. (2010) . Phytotoxic effect of the uranium on the growing up and development the plant of corn. Water, Air, and Soil Pollution. 209, 1-4 : 401-410.

Van Wyk, B. ; Van Wyk , P. (1997). "Field Guide to Trees of Southern Africa". Struik, Cape Town, South Africa. 